
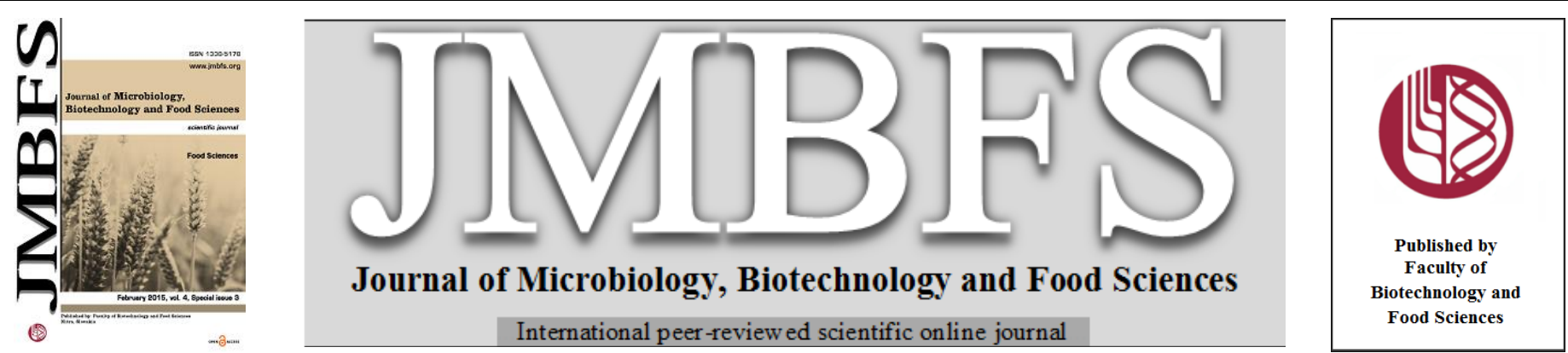

\title{
EFFECT OF ARSENIC ON DRY WEIGHT AND RELATIVE CHLOROPHYLL CONTENT IN GREENINGMAIZE AND SUNFLOWER TISSUES
}

\section{Szilvia Várallyay*l, Éva Bódi ${ }^{1}$, Farzaneh Garousi ${ }^{1}$, Szilvia Veres $^{2}$, Béla Kovács ${ }^{1}$}

Address(es): Szilvia Várallyay

${ }^{1}$ University of Debrecen, Faculty of Agricultural and FoodSciences and Environmental Management, Institute of Food Science,Bösz örményi str. 138 ., 4032 Debrecen,Hungary.

${ }^{2}$ University of Debrecen, Faculty of Agricultural and Food Sciences and Environmental Management, Institute of Crop Sciences, Department of Agricultural Botany, Crop Physiology and Biotechnology,Böszörményi str. 138., 4032 Debrecen, Hungary.

*Corresponding author: varallyay.szilvia@agr.unideb.hu

doi: 10.15414/jmbfs.2015.4.special3.167-169

\section{ART ICLE INFO}

Received 27.11.2014

Revised 3. 12. 2014

Accepted 4. 12. 2014

Published 2. 2. 2015

Regular article

open $\partial_{\text {ACCESS }}$

\begin{abstract}
Arsenic is one of the most toxic elements that can be found in the environment. Excessive uptake of arsenic may cause physiological changes in plants. The aim of the study was to investigate the effect of different arsenic treatments on relative chlorophyll content and dry weight of shoot and root of maize and sunflower in the early phases of plant development. Seedlings were grown in climatic room in nutrient solution under strictly regulated environmental conditions. The plants were exposed to 3,10 and $30 \mathrm{mg} \mathrm{kg} \mathrm{arsenic,} \mathrm{whereas}^{-1}$ there was no arsenic treatment on the control plants. We applied arsenic in the form of arsenite $\left(\mathrm{NaAsO}_{2}\right)$ and arsenate $\left(\mathrm{KH}_{2} \mathrm{AsO}_{4}\right)$, respectively. After 14 days of arsenic treatments, changes in relative chlorophyll content and dry weight of maize shoots and roots were recorded. In the case of sunflower these physiological parameters were measured after 21 day. The applied arsenic decreased the relative chlorophyll content of maize and sunflower leaves, especially at concentration of $30 \mathrm{mg} \mathrm{kg}^{-1}$. The increasing amount of As treatment were resulted the lower weight of the experimental plants, which was more considerable in the case of the roots. The results indicate that the sunflower plants is more sensitive to arsenic toxicity than maize plants and all data demonstrate that the $\mathrm{As}(\mathrm{III})$ is more toxic to these crop plants than the $\mathrm{As}(\mathrm{V})$.
\end{abstract}

Keywords: Arsenic, maize seedling, sunflower seedling, dry weight, relative chlorophyll content

\section{INTRODUCTION}

Arsenic (As) is an environmental toxin that is found naturally in soils all over the world (Smedley and Kinniburgh, 2002). The sources of arsenic pollution are mining activities, use of arsenical herbicides and insecticides, irrigation with arsenic contaminated groundwater and some other agricultural and anthropogenic factors(Stoeva et al., 2003; Zhao et al., 2008). Arsenic contamination of soil and groundwater is a global environmental problem affecting a large number of populations(Shaofen Wang et al., 2004). Arsenic becomes part of the food chain when crops and fodder become contaminated (M. Finnegan et al., 2012). Arsenic is nonessential and toxic to plants (Kim et al., 2012).Arsenic phytotoxicity depends on the form and availability of arsenic. Inorganic arsenic compounds are more toxic than organic compounds(Adriano, 1986).

Arsenic in soil and in groundwater mostly found as trivalent arsenite (As(III)) or pentavalent arsenate $(\mathrm{As}(\mathrm{V}))$. Both are toxic, however, arsenite is the more toxic form, because able to react with sulfhydryl groups of enzymes inhibit the cellular function. Cellular membranes become damaged in plants, which causing electrolyte leakage (M. Finnegan et al., 2012).Arsenic is chemically very similar to phosphorus, an essential plant nutrient, which is necessary for plant growth. The behavior of arsenate seems analogous to phosphate. Phosphorus and arsenic share the same transport pathway in higher plant, so the plant also takes in arsenic from the environment, and it causes inhibition of shoot and root growth, reduction of chlorophylls and germination, lead to low grain yield and finally death.

Roots are usually the first tissue to be exposed to As (M. Finnegan et al., 2012).The root system is the primary site of damages when the amount of arsenic reaches the level of toxicity (O'Neill, 1995). When As is absorbed into plant roots in the form of arsenate, it is reduced to arsenite (Kim et al., 2008). Roots accumulated higher concentration than the shoot. Uptake of arsenic by the cell of the plant roots increasing with increasing arsenic concentration (Porter and Peterson, 1975).

Some studies have reported photosynthetic pigments were also negatively affected by As (Farnese et al., 2014; Leão et al., 2013).The weight decrease in plant may be related with the decrease in the photosynthetic process and in the photosynthetic (Mascher et al., 2002).

The objective of our study was to investigate the effect of arsenic on relative chlorophyll content and dry weight of shoot and root of maize and sunflower in the early growth phases.

\section{MATERIAL AND METHODS}

\section{Plants and growing conditions}

To arrange germination, the sunflower seeds were sterilized with $10 \% \mathrm{H}_{2} \mathrm{O}_{2}$ for 10 min and washing in distilled water, in the case of maize after that the seeds soaked in $0.2 \mu \mathrm{M} \mathrm{CuSO}_{4}$.

Seeds of maize and sunflower were germinated bet ween moist filter paper and after 3 days seedlings were transported into $1.7 \mathrm{dm}^{3}$ plastic pots containing an aerated nutrient solution of $2.0 \mathrm{mMCa}\left(\mathrm{NO}_{3}\right)_{2}, 0.7 \mathrm{mMK}_{2} \mathrm{SO}_{4}, 0.5 \mathrm{mMMgSO}_{4}$, $0.1 \mathrm{mM} \mathrm{KH}_{2} \mathrm{PO}_{4}, 0.1 \mathrm{mMKCl}, 1 \mu \mathrm{M} \mathrm{MnSO}_{4}, 1 \mu \mathrm{M} \mathrm{ZnSO}_{4}, 0.2 \mu \mathrm{M} \mathrm{CuSO}_{4}, 0.01$ $\mu \mathrm{M}\left(\mathrm{NH}_{4}\right)_{6} \mathrm{Mo}_{7} \mathrm{O}_{24}, 10^{4} \mathrm{M}$ Fe-EDTA (Cakmak and Marschner, 1990).

Nutrient solution contained $0.1 \mu \mathrm{M} \mathrm{H}_{3} \mathrm{BO}_{3}$ in the case of maize and $10 \mu \mathrm{M}$ $\mathrm{H}_{3} \mathrm{BO}_{3}$ if the plant was sunflower. The nutrient solution were replaced twice a week. 
They were grown in climatic room under strictly controlled conditions. Irradiance of $300 \mathrm{~mol} \mathrm{~m}^{-2} \mathrm{~s}^{-1}, 16$-h day and 8-h night photoperiod, day/night temperat ure of $25 / 20^{\circ} \mathrm{C}$ and relative humidity of $65-75 \%$.

Maize and sunflower seedlings were exposed to $0,3,10$ and $30 \mathrm{mg} \mathrm{kg}^{-1}$ arsenic. We applied arsenic in two inorganic forms, namely arsenite $\left(\mathrm{NaAsO}_{2}\right)$ and arsenate $\left(\mathrm{KH}_{2} \mathrm{AsO}_{4}\right)$. The plants were treated separately with $\mathrm{As}(\mathrm{III})$ and $\mathrm{As}(\mathrm{V})$. At the end of the experimental period the tissues from all the plants were separated into the following parts: roots and shoots.

The dry weight (DW) of shoots and roots were measured after 14 days in the case of maize, and after 21 days in the case of sunflower. The dry weights were recorded after drying the shoots and roots at $65^{\circ} \mathrm{C}$

Relative chlorophyll content (RCC) was recorded on the final day of the experiment. RCC was obtained by using SPAD 502 (Soil Plant Analysis System) chlorophyll meter.

Chemicals were obtained from Sigma-Aldrich Ltd. (Poole, UK) and Chlorophyll meter (MinoltaSPAD-502) was supplied by Konica-Minolta, Japan.

\section{Data analysis}

All dat a were subjected to one-way analysis of variance(ANOVA) and Duncan's test test at 0.05 significance level, performed on SPSS statistics software version 22.

\section{RESULTS AND DISCUSSION}

\section{Effect of arsenic on dry weight of maize seedling tissues}

The effect of As (V) treatments on the shoots dry weight and roots dry weight of maize after 14 days is demonstrate in the table 1 .

Negative correlation was observed bet ween the higher concentration of $\mathrm{As}(\mathrm{V})$ in the nutrition solution and the dry weight of the maize shoots and roots. In maize, the shootsdry weight decreased by $57-76 \%$ in plants which treated with arsenate $3-30 \mathrm{mg} \mathrm{kg}^{-1}$, the roots dry weight decreased by $9-56 \%$.

Table 1 The effect of As (V) treatments $\left(\mathrm{mg}^{-\mathrm{kg}^{-1}}\right)$ on dry weight (DW) (g.plant ${ }^{-1}$ ) of maize seedlings roots and shoots. $n=4 \pm$ s.e.

\begin{tabular}{ccc}
\hline $\begin{array}{c}\text { As-treatments } \\
\left(\mathbf{m g . k g ^ { - 1 }}\right)\end{array}$ & DW of shoots & DW of roots \\
\hline $\mathbf{0}$ & $0.1462 \pm 0.0166^{\mathrm{c}}$ & $0.0456 \pm 0.0095^{\mathrm{b}}$ \\
$\mathbf{3}$ & $0.0624 \pm 0.0088^{\mathrm{b}}$ & $0.0413 \pm 0.0051^{\mathrm{b}}$ \\
$\mathbf{1 0}$ & $0.0432 \pm 0.0182^{\mathrm{ab}}$ & $0.0293 \pm 0.0117^{\mathrm{ab}}$ \\
$\mathbf{3 0}$ & $0.0344 \pm 0.0028^{\mathrm{a}}$ & $0.0200 \pm 0.0005^{\mathrm{a}}$ \\
\hline DW-dry weight & &
\end{tabular}

Dry mass of shoots and roots of maize plants decreased as a result of higher concentration of As(III) in the nutrient solution (table 2.).

Table 2 The effect of As(III) treatments (mg. $\left.\mathrm{kg}^{-1}\right)$ ondryweight (DW) (g.plant $^{-1}$ ) of maizeseedlingsroots and shoots. $n=4 \pm$ s.e.

\begin{tabular}{ccc}
\hline $\begin{array}{c}\text { As-treatments } \\
\left(\mathbf{m g ~ k g}^{-1}\right)\end{array}$ & DW of shoots & DW of roots \\
\hline $\mathbf{0}$ & $0.1462 \pm 0.0166^{\mathrm{c}}$ & $0.0456 \pm 0.0095^{\mathrm{b}}$ \\
$\mathbf{3}$ & $0.0700 \pm 0.0246^{\mathrm{b}}$ & $0.0356 \pm 0.0085^{\mathrm{b}}$ \\
$\mathbf{1 0}$ & $0.0328 \pm 0.0032^{\mathrm{a}}$ & $0.0280 \pm 0.0014^{\mathrm{ab}}$ \\
$\mathbf{3 0}$ & $0.0157 \pm 0.0051^{\mathrm{a}}$ & $0.0130 \pm 0.0013^{\mathrm{a}}$ \\
\hline DW-dry weight & &
\end{tabular}

The dry weight of the control maize plants shootswereapproximately9 timeshigherthaninthecase of $30 \mathrm{mg} \mathrm{kg}^{-1} \mathrm{As}$ (III) treatment.The shoots dry weight decreased by $50-78 \%$, if the plants were treated with 3 and $10 \mathrm{mg} \cdot \mathrm{kg}^{-1}$. In the case of roots the results didnot showsignificant difference bet ween the control and the 3-10 mg. $\mathrm{kg}^{-1}$ treatments.If the nutrient solution contained $30 \mathrm{mg} \cdot \mathrm{kg}$ ${ }^{1} \mathrm{As}(\mathrm{III})$ the dry weight of roots decreased by $71 \%$ compared to the control. The result shows the same tendency than Stoeva et al. (2003) found in their research about the maize.

\section{Effect of arsenic on dry weight ofsunflower see dling tissues}

The presence of $\mathrm{As}(\mathrm{V})$ in the nutrient solution caused an reduction in the weight of sunflower seedlings (table 3 .)

Table 3 The effect of As (V) treatments $\left(\mathrm{mg}^{-\mathrm{kg}^{-1}}\right)$ on dry weight (DW) (g.plant $^{-1}$ ) of sun flower seedlings roots and shoots. $n=4 \pm$ s.e.

\begin{tabular}{ccc}
$\begin{array}{c}\text { As-treatments } \\
\left(\mathbf{m g . k g}^{-1}\right)\end{array}$ & DW of shoots & DW of roots \\
\hline $\mathbf{0}$ & $0.1830 \pm 0.0445^{\mathrm{c}}$ & $0.0657 \pm 0.0221^{\mathrm{ab}}$ \\
$\mathbf{3}$ & $0.0965 \pm 0.0165^{\mathrm{b}}$ & $0.0413 \pm 0.0338^{\mathrm{b}}$ \\
$\mathbf{1 0}$ & $0.0335 \pm 0.0195^{\mathrm{a}}$ & $0.0329 \pm 0.0212^{\mathrm{ab}}$ \\
$\mathbf{3 0}$ & $0.0267 \pm 0.0080^{\mathrm{a}}$ & $0.0079 \pm 0.0013^{\mathrm{a}}$ \\
\hline DW-dry weight & &
\end{tabular}

This values show that increasing amount of As (V) treatment resulted the lower average weight of the experimental plants. Sunflower seedlings that had been subjected to 3 and $10 \mathrm{mg} \cdot \mathrm{kg}^{-1} \mathrm{As}(\mathrm{V})$ stress, shoot dry weight were reduced 47 $18 \%$. In the case of shoot dry weight there was no significant difference bet ween the 10 and $30 \mathrm{mg} \cdot \mathrm{kg}^{-1}$ teratments. The control plant root dry weight was 1.5 times higher than case of $3 \mathrm{mg} \cdot \mathrm{kg}^{-1}$ and dry mass of roots were less than $0.1 \mathrm{~g}$ in all cases.

The weight of sunflower shoots and roots decreased with the different concentration of As (III) treatment that have beendemonstrated in table 4 .

Table4 The effect of As (III) treatments (mg.kg ${ }^{-1}$ ) ondry weight (DW) (g.plant $^{-1}$ ) of sunflowerseedlingroots and shoots. $\mathrm{n}=4 \pm$ s.e.

\begin{tabular}{ccc}
\hline $\begin{array}{c}\text { Astreatments } \\
\left(\mathbf{m g . k g ^ { - 1 } )}\right.\end{array}$ & DW of shoots & DW of roots \\
\hline $\mathbf{0}$ & $0.1830 \pm 0.0445^{\mathrm{c}}$ & $0.0457 \pm 0.0221^{\mathrm{a}}$ \\
$\mathbf{3}$ & $0.0942 \pm 0.0092^{\mathrm{b}}$ & $0.0494 \pm 0.0015^{\mathrm{a}}$ \\
$\mathbf{1 0}$ & $0.0408 \pm 0.0020^{\mathrm{ab}}$ & $0.0214 \pm 0.0061^{\mathrm{a}}$ \\
$\mathbf{3 0}$ & $0.0154 \pm 0.0019^{\mathrm{a}}$ & $0.0117 \pm 0.0019^{\mathrm{a}}$ \\
\hline DW-dry weight & &
\end{tabular}

Atthe end of the 14 daysperiod of arsenicstress, thedrymass of root sdecreased4992\% compared to the control. Whenwetreatedthe sunflower plantsinthe earlygrowthphases of plantdevelopmentwith3 mg. $\mathrm{kg}^{-1}$ arseniteor more, wefoundthattheaveragedry weight of shootsmassreducedfrom $0.1830 \mathrm{~g}$ to less than $0.1 \mathrm{~g}$.

Comparedthephysiological response of maize and sunflower to the different arsenic treatments, we found that the maize was more tolerant to arsenic exposure than the sunflower.

\section{Effect of arsenic on relative chlorophyll content of maize and sunflower seedlings}

Theresult of our research on relative chlorophyll content of maize and sunflower seedlings are summarized in table 5 and in table6.

The relative chlorophyll content in the leaves of maize changed to presence of $\mathrm{As}(\mathrm{III})$ and $\mathrm{As}(\mathrm{V})$ as compared to control. Inthecase of As(III) treatmentthelevel of relative chlorophyll contentat $3 \mathrm{mg} \cdot \mathrm{kg}^{-1}$ and1 $0 \mathrm{mg} \cdot \mathrm{kg}^{-1}$ increased by 10 and14\%, respectively. The highest $\mathrm{As}(\mathrm{III})$ concentration caused increase of relative chlorophyll content by $21 \%$. In the case of $\mathrm{As}(\mathrm{V})$ the maize seedlings relative chlorophyll content decrease by $9-18 \%$, if the plant was treated with 3-30 $\mathrm{mg} \mathrm{kg}^{-1}$. 
Table 5 The effect of As (III) and As (V) treatments (mg.kg ${ }^{-1}$ ) on relative chlorophyll content (RCC) of maize seedlings leaves. $n=4 \pm$ s.e.

\begin{tabular}{|c|c|c|}
\hline $\begin{array}{l}\text { As-treatments } \\
\left(\mathrm{mg}^{\left.-\mathrm{kg}^{-1}\right)}\right.\end{array}$ & $\operatorname{RCC}(\operatorname{As}(V))$ & $\operatorname{RCC}(\operatorname{As}(\mathrm{III}))$ \\
\hline 0 & $42.16 \pm 0.96^{\mathrm{c}}$ & $42.16 \pm 0.98^{\mathrm{d}}$ \\
\hline 3 & $38.26 \pm 0.66^{\mathrm{b}}$ & $38.10 \pm 0.98^{\mathrm{c}}$ \\
\hline 10 & $36.93 \pm 1.60^{\mathrm{a}}$ & $36.10 \pm 0.40^{\mathrm{b}}$ \\
\hline 30 & $34.53 \pm 0.33^{\mathrm{a}}$ & $33.37 \pm 0.14^{\mathrm{a}}$ \\
\hline
\end{tabular}

In the case of sunflower the changes inrelative chlorophyll content followed the same tendency. The average relative chlorophyll content of sunflower 42.16, when the sunflower was grown in nutrient solution without As treatment. The highest decrease in the relative chlorophyll content observed at concentration of $30 \mathrm{mg} \cdot \mathrm{kg}^{-1}$.

Table 6 The effect of As (III) and As (V) treatments (mg.kg $\left.{ }^{-1}\right)$ on relative chlorophyll content (RCC) of sunflower seedlings leaves. $\mathrm{n}=4 \pm$ s.e.

\begin{tabular}{|c|c|c|}
\hline $\begin{array}{l}\text { As-treatments } \\
\left(\mathbf{m g} \cdot \mathrm{kg}^{-1}\right)\end{array}$ & $\operatorname{RCC}(\operatorname{As}(V))$ & $\operatorname{RCC}(\operatorname{As}($ III) $)$ \\
\hline 0 & $42.00 \pm 0.05^{\mathrm{a}}$ & $42.00 \pm 0.57^{\mathrm{c}}$ \\
\hline 3 & $40.40 \pm 0.25^{b}$ & $39.53 \pm 0.38^{b}$ \\
\hline 10 & $38.46 \pm 0.46^{\mathrm{ab}}$ & $36.76 \pm 0.29^{\mathrm{a}}$ \\
\hline 30 & $36.48 \pm 0.62^{c}$ & $36.53 \pm 0.33^{\mathrm{a}}$ \\
\hline
\end{tabular}

RCC- relative chlorophyll content

\section{CONCLUSION}

This study provides important information concerning the relationship between the endogenous levels of As in plants and its impact on dry weight and relative chlorophyll content.

Result of our experiments shows treatments of the maize and sunflower roots with As had a negative effect on relative chlorophyll content and dry mass of shoots and roots.

We observed that sunflower plants is more sensitive to arsenic toxicity than maize plants and all data demonstrate that As (III) is more toxic to these plants than As (V).

\section{REFERENCES}

ADRIANO, D.C. 1986. TraceElements in the Terrestrial Environment. New York: Springer-Verlag. 219-262 p. ISBN:0-387-98678-2.

CAKMAK, I., MARSCHNER, H., 1990. Decrease in nitrate uptake and increase in proton release in zinc deficient cotton, sunflower and buckwheat plants. Plant and Soil. 129, 261-268.

FARNESE F.S., ALVES O., GUSMAN G.S., Leao G.A., SILVERIA N.M., SILVA P.E.M., RIBEIRO C., CAMBRAIA J. 2014. Effects of adding nitroprusside on arsenic stressed response of Pistia stratiotes L. under hydroponic conditions. International Journal of Phytoremediation, 16, 123-137. http://dx.doi.org/10.1080/15226514.2012.759532

KIM, D.J., PARK, H., LEE, S.H., NAMIN, K., KIM, J.GY. 2009.Arsenate tolerance mechanism of Oenothera odorata from a mine population involves the induction of phytochelatins in roots. Chemosphere, 75, 505-512. http://dx.doi.org/10.1016/j.chemosphere.2008.12.021

LEAO, G.A., OLIVEIRA, J.O., FELIPE R.T.A., FARNES F.S., GUSMAN G.S. 2014. Anthocyanins, thiols, and antioxidant scavenging enzymes are involved in Lemna gibba tolerance to arsenic. Journal of Plant Interactions, 9, 143-151. http://dx.doi.org/10.1080/17429145.2013.784815

MASCHER, R., LIPMANN, B., HOLZINGER, S., BERGMANN, H. 2002. Arsenate toxicity: effects on oxidative stress response molecules and enzymes in red clover plants. Plant Science, 163, 961-969. http://dx.doi.org/10.1016/s0168-9452(02)00245-5

M. FINNEGAN, P., CHEN, W. 2012. Arsenic Toxicity: The effects on plant metabolism. Front Physiol, 3, 182.http://dx.doi.org/10.3389/fphys.2012.00182 O'NEILL, P. 1995. Arsenic. In B. J. Alloway, ed. Heavy metals in soils, $2^{\text {nd }}$ ed., New York. 105-119 p.

PORTER, E.K., PETERSON, P.J. 1975. Arsenic accumulation by plants on mine waste (United Kingdom). Science of The Total Environment. 4, 356-371. http://dx.doi.org/10.1016/0048-9697(75)90028-5

SHAOFEN WANG, J., M. WAI, C. 2004. Arsenic in DrinkingWater - A GlobalEnvironmentalProblem.Journal of Chemical Education, 81(2), 207.http://dx.doi.org/10.1021/ed081p207

SMEDLEY, P. L., KINNIBURGH, D. G. 2002. A review of the source, behaviour and distribution of arsenic in natural waters. Applied Geochemistry. 17 517-568.http://dx.doi.org/10.1016/s0883-2927(02)00018-5

ST OEVA, N., BEROVA, M., ZLATEV, Z. 2003. Physiological response of maize to arsenic contamination.Biologia Plantarum, 47, 449-452. http://dx.doi.org/10.1023/b:biop.0000023893.12939.48

ZHAO, F.J., MA, J.F., MEHARG, A.A., MCGRATH, S.P. 2009. Arsenic uptake and metabolism in plants. New phytologist, 181, 777 794.http://dx.doi.org/10.1111/j.1469-8137.2008.02716.x 